OPEN ACCESS

Edited by:

Stephen M. Mureithi, University of Nairobi, Kenya

Reviewed by: Liming Ye,

Ghent University, Belgium Vincent Kathumo,

University of Nairobi, Kenya

*Correspondence: Wolde Mekuria w.bori@cgiar.org

Specialty section: This article was submitted to Conservation and Restoration

Ecology,

a section of the journal

Frontiers in Ecology and Evolution

Received: 26 November 2021 Accepted: 10 January 2022

Published: 31 January 2022

Citation:

Yakob G, Smith JU, Nayak DR, Hallett PD, Phimister E and Mekuria W (2022) Changes in Soil Properties Following the Establishment of Exclosures in Ethiopia: A Meta-Analysis.

Front. Ecol. Evol. 10:823026. doi: $10.3389 /$ fevo.2022.823026

\section{Changes in Soil Properties Following the Establishment of Exclosures in Ethiopia: A Meta-Analysis}

\author{
Getahun Yakob ${ }^{1,2,3}$, Jo U. Smith ${ }^{1}$, Dali R. Nayak', Paul D. Hallett ${ }^{1}$, Euan Phimister ${ }^{2,4}$ and \\ Wolde Mekuria ${ }^{5 *}$ \\ ${ }^{1}$ School of Biological Sciences, University of Aberdeen, Aberdeen, United Kingdom, ${ }^{2}$ Business School, University \\ of Aberdeen, Aberdeen, United Kingdom, ${ }^{3}$ Southern Agricultural Research Institute, Hawassa, Ethiopia, ${ }^{4}$ Business School, \\ University of Stellenbosch, Cape Town, South Africa, ${ }^{5}$ International Water Management Institute (IWMI), Addis Ababa, \\ Ethiopia
}

Community-led watershed development activities, including the establishment of exclosures (areas where both livestock and farming activities are excluded) on degraded communal grazing land, have become a common practice in Ethiopia since the 1990s. However, it is not yet fully understood how these exclosures change soil organic carbon and total soil nitrogen in different soil types and under different agroecologies. A meta-analysis using data gathered from the most relevant peer reviewed articles from Ethiopian exclosure systems was conducted to assess the variation in the effects of exclosures on soil carbon and nitrogen and to investigate the factors controlling change. The results demonstrate that after 16 years, exclosures can increase soil organic carbon and total soil nitrogen up to an effect size greater than two. This is moderated by soil type, exclosure age, landscape position and agroecology. More effective restoration of soil carbon was observed in less developed Leptosols and Cambisols than in more developed Luvisols, and in drier than more humid agroecologies. The results suggest that soil type and agroecology should be taken into consideration when planning and implementing exclosures on degraded communal grazing land. The findings of this study provide base line information for the future expansion of exclosures, and guide where to focus implementation. They also provide criteria to be used when planning and establishing exclosures to restore soil carbon and nitrogen. In addition, the results generated through this meta-analysis provide better understanding of the spatial and temporal variation of the effectiveness of exclosures to restore soil carbon and nitrogen.

Keywords: agroecology, exclosure age, grazing land, restoration of degraded lands, soil types

\section{INTRODUCTION}

Land degradation, resulting in long-term loss of ecosystem services, is one of the world's most pressing environmental problems (IPBES, 2018). A report on progress toward achieving Sustainable Development Goal (SDG) 15 (life on earth) indicated that 20\% of the Earth's total land area was degraded between 2000 and 2015, resulting in a significant loss of key services underpinning food production, clean water and emissions of greenhouse gases (SDG Report, 2019). Currently, degradation of the Earth's land surface through human activities 
TABLE 1 | Categories of exclosures established at different time periods.

\begin{tabular}{lc}
\hline Ages of exclosures & Category \\
\hline Exclosures with ages between 1 and 5 years & Group 1 \\
Exclosures with ages between 6 and 10 years & Group 2 \\
Exclosures with ages between 11 and 15 years & Group 3 \\
Exclosures with ages greater than and equals to 16 years & Group 4 \\
\hline
\end{tabular}

is negatively impacting the well-being of at least $3.2 \times 10^{9}$ people and costing more than $10 \%$ of the annual global gross product in loss of biodiversity and ecosystem services (IPBES, 2018). Almost all terrestrial biomes, agroecologies, and economies are affected by land degradation. It may pose a particularly serious threat to food production and rural livelihoods in poor and densely populated areas of the developing world (Global Mechanism of the UNCCD et al., 2019).
As in other developing countries, land resources in Ethiopia are facing intense degradation due to deforestation, soil erosion, agricultural land expansion, and overgrazing (Nyssen et al., 2004). Addressing land degradation has become a major policy objective in Ethiopia, where agricultural growth is an important element of economic and social development (Haregeweyn et al., 2015). About 75\% of Ethiopians work in agriculture, producing $80 \%$ of Ethiopia's exports and $40 \%$ of Gross Domestic Product (Neglo et al., 2021). An 8.35\% growth in agricultural value since 2014 has decreased poverty. In line with this, the restoration of degraded landscapes in the country, through implementation of various sustainable land management practices has been underway since the 1980s (Woldeamlak, 2006; Adimassu et al., 2013). To achieve regional and international commitments and to address SDGs, the government of Ethiopia has recently started community-based watershed development activities (Holden et al., 2001).

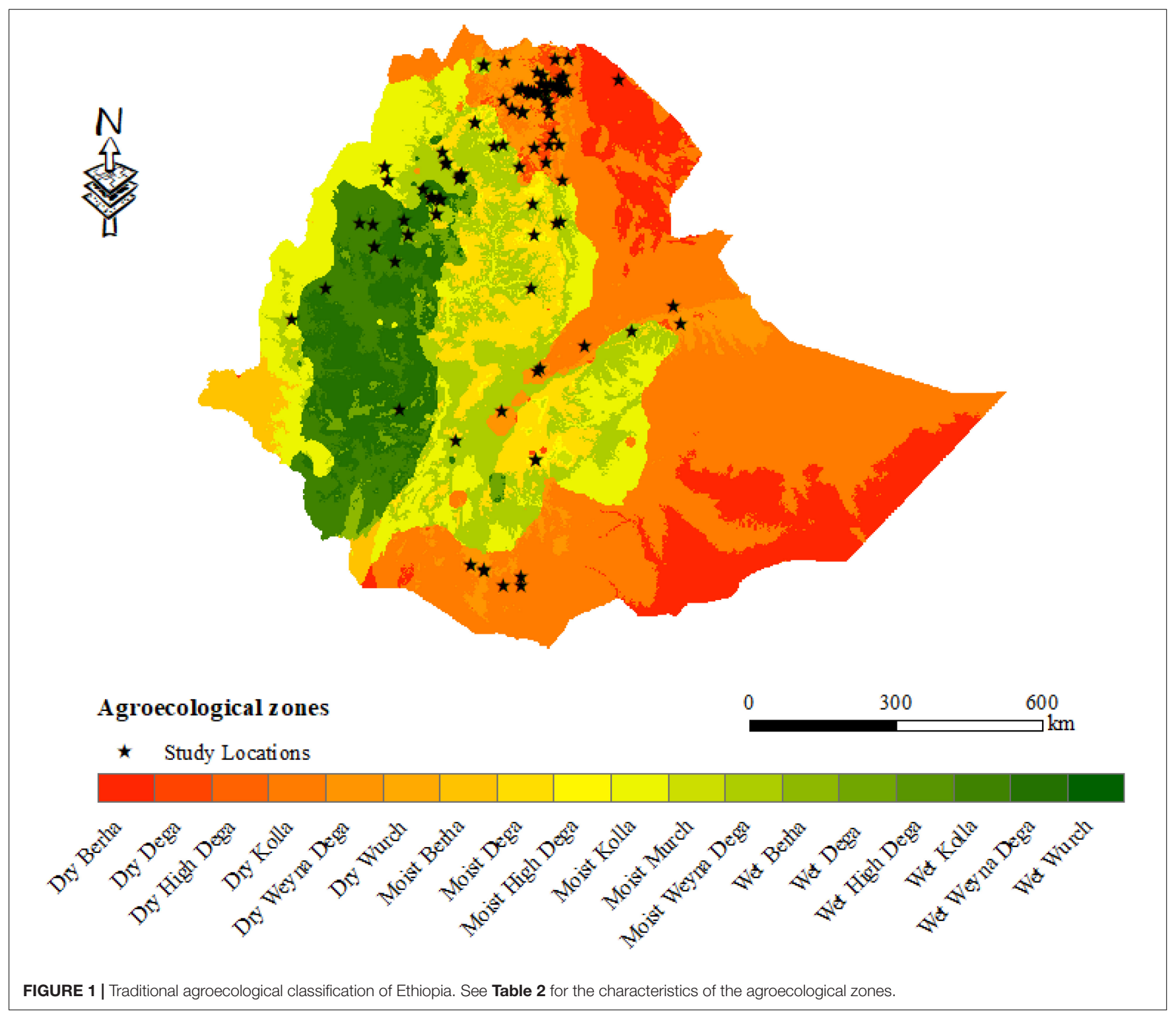


As part of the African Forest Landscape Restoration Initiative (AFR100), which is a regional commitment that aims to restore 100 million ha of degraded landscapes across Africa, the government of Ethiopia has pledged to restore 7 million ha of degraded land by 2030 (about 6\% of total land area) through the establishment of "exclosures." Exclosures are communal areas that traditionally allowed access to all, but where wood cutting, grazing and other agricultural activities are now forbidden or strictly limited to promote restoration and natural regeneration (Aerts et al., 2009; Teketay et al., 2010). The overall area covered by exclosures in Ethiopia is currently increasing by $2 \%$ every year and could reach 5-7 million ha by the early 2030 s.

This increase in the area under exclosures can be attributed to many perceived benefits; restoring degraded landscapes (Girmay et al., 2009; Mekuria et al., 2009; Ebabu et al., 2019), increasing

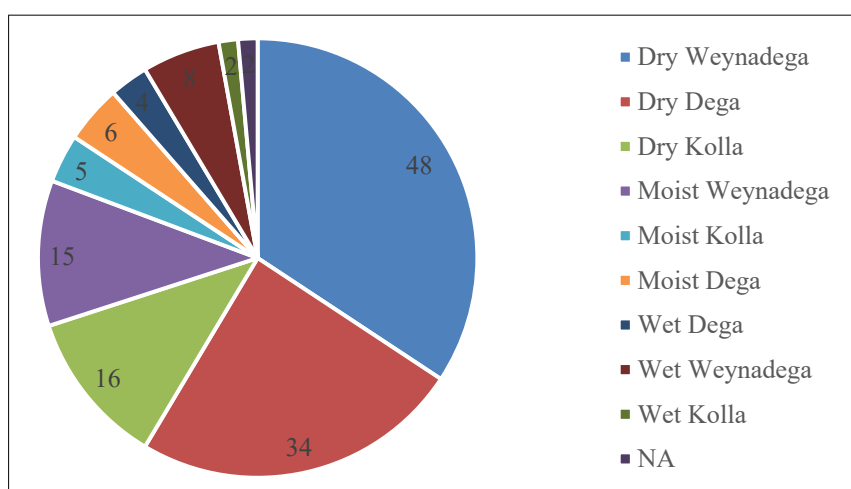

FIGURE 2 | Distribution of publications across the nine traditional agroecologies. The values in each agroecological zone indicate the number of publications. NA refers to no data.

TABLE 2 | Characteristics of the traditional agroecological zones of Ethiopia.

\begin{tabular}{|c|c|c|}
\hline Agroecology & $\begin{array}{l}\text { Annual precipitation } \\
\qquad(\mathrm{mm})\end{array}$ & $\begin{array}{c}\text { Elevation (m } \\
\text { above sea level) }\end{array}$ \\
\hline Dry Wurch & $<900$ & Above 3,700 \\
\hline Moist Wurch & $900-1,400$ & \\
\hline Wet Wurch & $>1,400$ & \\
\hline Dry High Dega & $<900$ & $3,200-3,700$ \\
\hline Moist High Dega & $900-1,400$ & \\
\hline Wet High Dega & $>1,400$ & \\
\hline Dry Dega & $<900$ & $2,300-3,200$ \\
\hline Moist Dega & $900-1,400$ & \\
\hline Wet Dega & $>1,400$ & \\
\hline Dry Weynadega & $<900$ & $1,500-2,300$ \\
\hline Moist Weynadega & $900-1,400$ & \\
\hline Wet Weynadega & $>1,400$ & \\
\hline Dry Kolla & $<900$ & $500-1,500$ \\
\hline Moist Kolla & $900-1,400$ & \\
\hline Wet Kolla & $>1,400$ & \\
\hline Dry Berha & $<900$ & Below 500 \\
\hline Moist Berha & $900-1,400$ & \\
\hline Wet Berha & $>1,400$ & \\
\hline
\end{tabular}

Source: Hurni et al., 2015. soil carbon (C) sequestration (Mekuria et al., 2011; Gessesse et al., 2020), and improving other ecosystem services (Rossiter et al., 2017; Gebre et al., 2019). Positive opportunities for livelihood diversification and enhancement may result, with decreased soil erosion and subsequent sedimentation in farmland and rivers downslope of the exclosure areas (Descheemaeker et al., 2006; Nyssen et al., 2006). This can boost agricultural productivity and livelihoods in the surrounding areas over the medium to long term (Mekuria et al., 2020).

Most of the studies cited above have reported the effectiveness of exclosures in restoring degraded landscapes and ecosystem services, as well as improving the livelihood of local communities. However, studies that aim to better understand the effects of exclosures on soil properties are fragmented and have been conducted under a range of different agroecologies, soil types and management practices. Underpinning the functioning of any soil is the amount of $\mathrm{C}$ stored, which decreases erosion by aggregating unstable soil particles, improves water storage and is accompanied by nutrients such as nitrogen $(\mathrm{N})$ that improves plant productivity (Lal, 2010). To draw out generalizable results from existing studies, available information on the effectiveness of exclosures for restoring soil organic $\mathrm{C}$ and total soil $\mathrm{N}$ under different conditions needs to be synthesized. Although such syntheses are critical for improving the impact of exclosures on soils, this has not yet been done for Ethiopia. This more holistic assessment is particularly important because of the key role agriculture continues to play in development and poverty alleviation in Ethiopia and the example of successful agricultural led development it has provided to the rest of Sub-Saharan Africa (World Bank, 2016). Therefore, this meta-analysis aims to synthesize the results of fragmented studies in Ethiopia, to evaluate the impacts of exclosures in different agroecologies, soil types and climates, and to scale up these findings to the national level, developing strategies for the use of exclosures to restore degraded landscapes. Specifically, the study aims to evaluate (i) the effects of exclosure age on soil organic $\mathrm{C}$ and total soil $\mathrm{N}$ compared to communal grazing lands, (ii) the changes in soil organic $\mathrm{C}$ and total soil $\mathrm{N}$ under exclosures compared to cropland

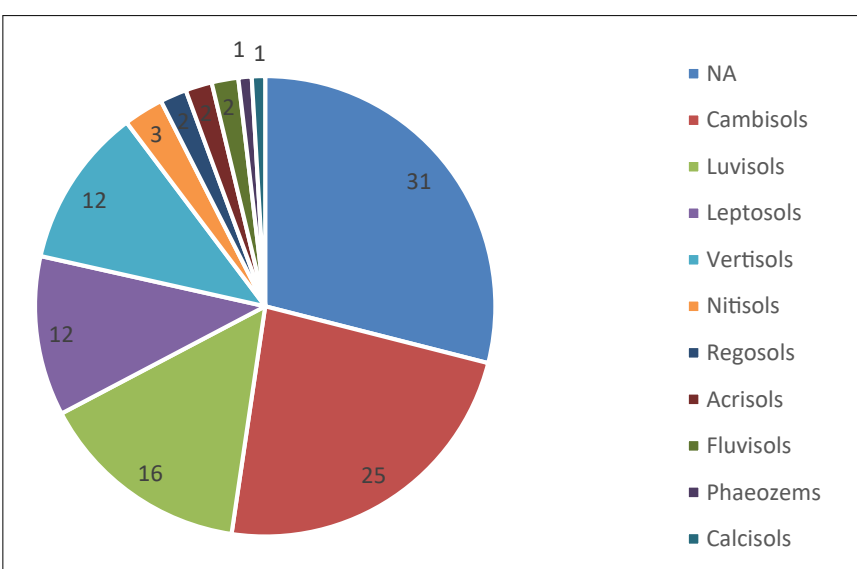

FIGURE 3 | Major soil types, defined by World Reference Base Reference Soil Groups, of the study areas covered by the studies. 
and Eucalyptus plantation, and (iii) the influence of landscape position down the slope on the effectiveness of exclosures for restoring degraded soils.

\section{MATERIALS AND METHODS}

Relevant literature was collated during 2020 and 2021 from the online databases, Science Direct, Scopus and CAB abstracts. The terms used in the primary literature search (both separately and in combination) were "exclosures," "area closure," "enclosure," "soil carbon," "grazing lands," "land uses," "land degradation," and "Ethiopia." This identified a total of 127 peer reviewed articles published between 2002 and 2020. In the second stage, 89 papers that reported the effects of exclosures on ecosystem services were identified. Finally, 30 papers that reported the effects of exclosures on soil organic $\mathrm{C}$ and total soil $\mathrm{N}$, quoting means and standard deviations and providing the information needed for the metaanalysis (agroecology, soil type, comparison of exclosures with adjacent grazed land, cropland, and eucalyptus plantation) were selected. Only papers published in peer reviewed international journals were considered. Studies conducted outside Ethiopia and reviews and modeling studies were not included in the metaanalysis. The values required to calculate the effect sizes, mean, sample size and a measure of variance (standard deviation or standard error) for both control (i.e., grazing lands, croplands, and eucalyptus plantation adjacent to exclosures) and treatment groups (i.e., exclosures) were extracted from the papers. The data were categorized according to agroecology, soil type and time since exclosure establishment (Table 1). The analysis assumed that the exclosures and adjacent communal grazing lands, croplands and eucalyptus plantation had similar conditions before the establishment of the exclosures.

A meta-analysis was used to evaluate the changes in soil organic $\mathrm{C}$ and total soil $\mathrm{N}$ under different agroecologies and soil types following the establishment of exclosures on degraded communal grazing lands and croplands, as well as comparing soil organic $\mathrm{C}$ and total soil $\mathrm{N}$ in exclosures and adjacent eucalyptus plantations. The effect of landscape position on the effectiveness of exclosures to restoration of soil organic $\mathrm{C}$ and total soil $\mathrm{N}$ were also investigated. This work only considered the changes in soil organic $\mathrm{C}$ and total soil $\mathrm{N}$ in the $0-20 \mathrm{~cm}$ depth. The analysis used the calculated soil organic $\mathrm{C}$ and total soil $\mathrm{N}$ expressed in $\mathrm{Mg} \mathrm{ha}^{-1}$ derived from \% soil organic $\mathrm{C}$ and \% total soil $\mathrm{N}$ and bulk density presented in each paper. The form of total soil $\mathrm{N}$ is also important, but such data were not available in some of the studies collected so we only considered all forms of $\mathrm{N}$ together.

The meta-analysis followed the procedure described by Rosenberg et al. (2000). A random effects model was used to conduct a meta-analysis. This model is one of the most employed statistical models for ecological data, which assumes that differences between treatments are not only due to sampling error but also due to true random variation (Gurevitch and Hedges, 1999). The analyses were conducted using OpenMEE (Open Meta-analyst for Ecology and Evolution) software (Wallace et al., 2017). To minimize heterogeneity in the data, the analysis was completed using sub-groups.

The calculated effect sizes were used to evaluate the changes following establishment of exclosures on degraded communal grazing lands and croplands and to compare the effects on soil organic $\mathrm{C}$ and total soil $\mathrm{N}$ of exclosures compared to eucalyptus plantation. The effect size, Hedges' $d$, was calculated using Equation 1 (Hedges, 1981),

$$
d=\frac{\left(X_{e}-X_{c}\right) J}{S_{p}}
$$

where $X_{e}$ is the sample mean of the treatment (exclosure), $X_{c}$ is the sample mean of control (grazing land, cropland, or eucalyptus plantation adjacent to the exclosure), $S_{p}$ is the pooled

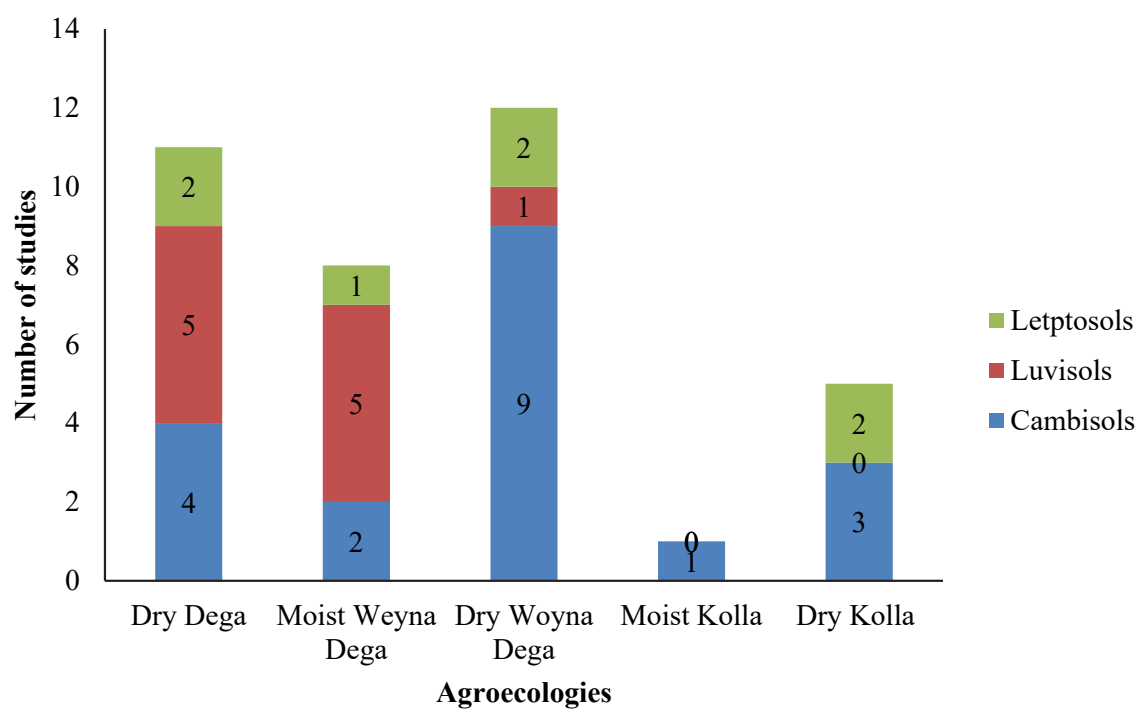

FIGURE 4 | Distribution of the three soil types across the agroecological zones. 

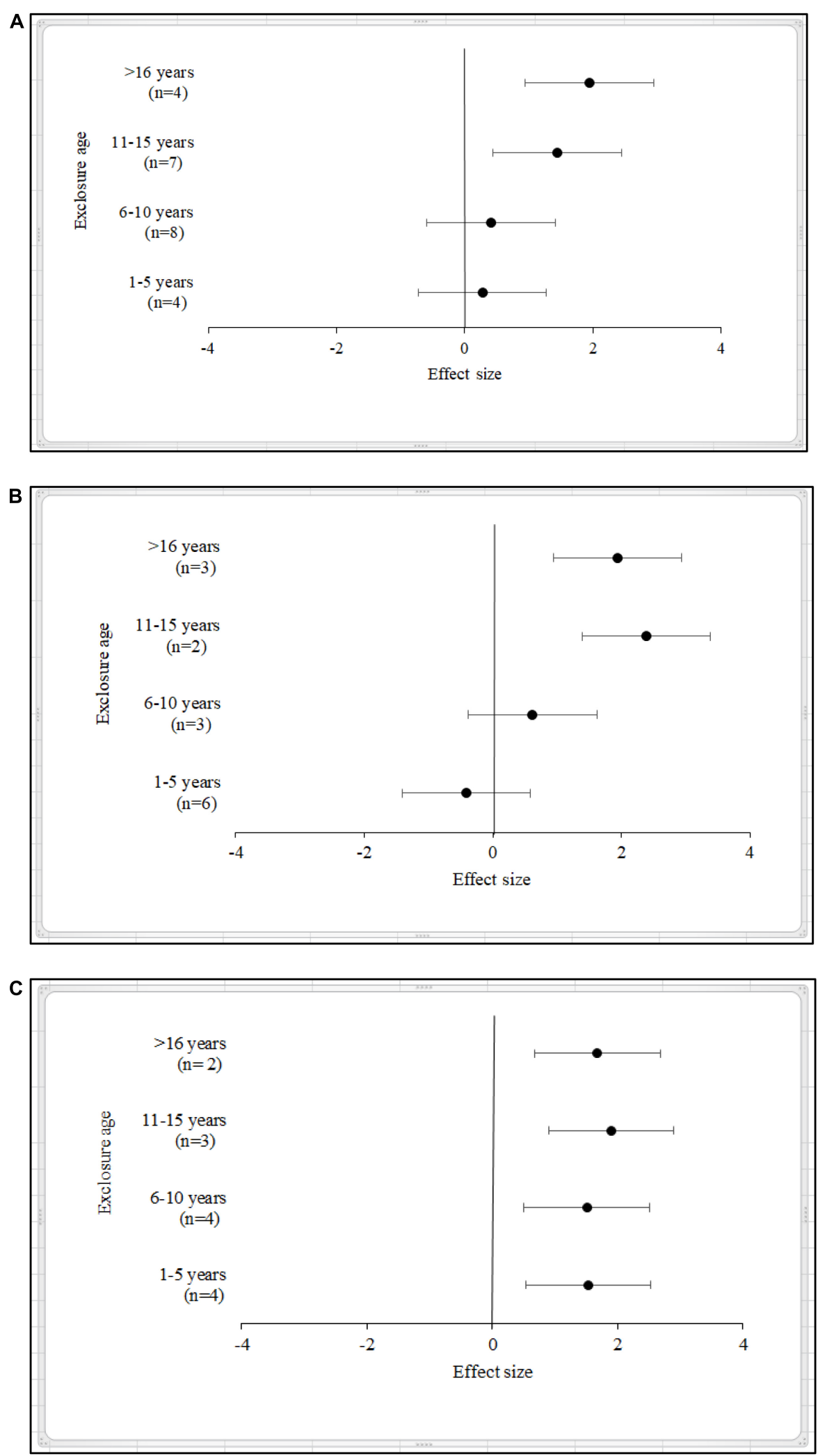

FIGURE 5 | Changes in soil organic carbon following establishment of exclosures on communal grazing lands in Ethiopia: (A) Cambisols, (B) Luvisols, and (C) Leptosols. Values are effect sizes with 95\% confidence intervals (Cl). A significant response is when the $\mathrm{Cl}$ does not overlap with zero. The number of observations in each age category is shown in parenthesis. 
standard deviation and $J$ is the weighting factor based on the number of replicates per treatment. The number of replicates was obtained from the number reported in the reviewed paper for the particular variable. The pooled standard deviation $\left(S_{p}\right)$ and the weighting factors $(J)$ were calculated using Equations 2, 3, respectively (Hedges, 1981),

$$
\begin{gathered}
S_{p}=\sqrt{\frac{\left(S_{e}^{2}\left(N_{e}-1\right)+S_{c}^{2}\left(N_{c}-1\right)\right)}{\left(N_{e}+N_{c}-2\right)}} \\
J=1-\frac{3}{4\left(N_{e}+N_{c}-2\right)-1}
\end{gathered}
$$

where $N_{e}$ and $N_{c}$ are the number of replicates, and $S_{e}{ }^{2}$ and $S_{c}{ }^{2}$ are the standard deviations of the treatment and control groups, respectively.

The variance of $d\left(V_{d}\right)$ was calculated using Equation 4 (Hedges, 1981),

$$
V_{d}=\frac{N_{e}+N_{c}}{N_{e} \times N_{c}}+\frac{d^{2}}{2\left(N_{e}+N_{c}\right)}
$$

Standard deviation $(S)$ was derived from percent coefficient of variation $(\% C V)$ in cases where the reviewed papers only reported $C V$ using Equation 5,

$$
S=C V \times X
$$

where $X$ is the treatment or control mean value.
A positive value of effect size ${ }^{1}$ indicates the exclosure increases soil organic $\mathrm{C}$ or total soil $\mathrm{N}$ compared to the adjacent grazing land, cropland, or eucalyptus plantation, whereas negative values indicate it is decreased. If the value of the effect size is zero, there is no effect of the exclosures on the soil organic $\mathrm{C}$ and total soil $\mathrm{N}$ compared to the control. This also applies for the comparisons of the changes in soil organic $\mathrm{C}$ and total soil $\mathrm{N}$ among the different age groups. The calculated effect size was significantly different from zero if its 95\% confidence interval (CI) did not overlap with the zero.

\section{RESULTS}

\section{Research on Exclosures in Ethiopia}

Regional differences were observed within Ethiopia in terms of the efforts made to understand the effects of exclosures on soil organic $\mathrm{C}$ and total soil $\mathrm{N}$, and variables such as vegetation composition and diversity (Figure 1). Of the 89 papers published between 2001 to 2020 that investigated the changes in soil properties, other biophysical variables and socio-economic factors, 79\% were conducted in only two regions, Tigray and Amhara regions (Figure 1). Only $\sim 3 \%$ were conducted in Southern Nations, Nationalities, and People's Region (SNNPR), which covers $8.5 \%$ of Ethiopia's land area.

${ }^{1}$ Effect size is a statistical concept that measures the strength of the relationship between two variables on a numeric scale (Cohen, 1969). In meta-analysis, the effect size assesses the effect reported in different studies and is then used to combine all the studies into single analysis.

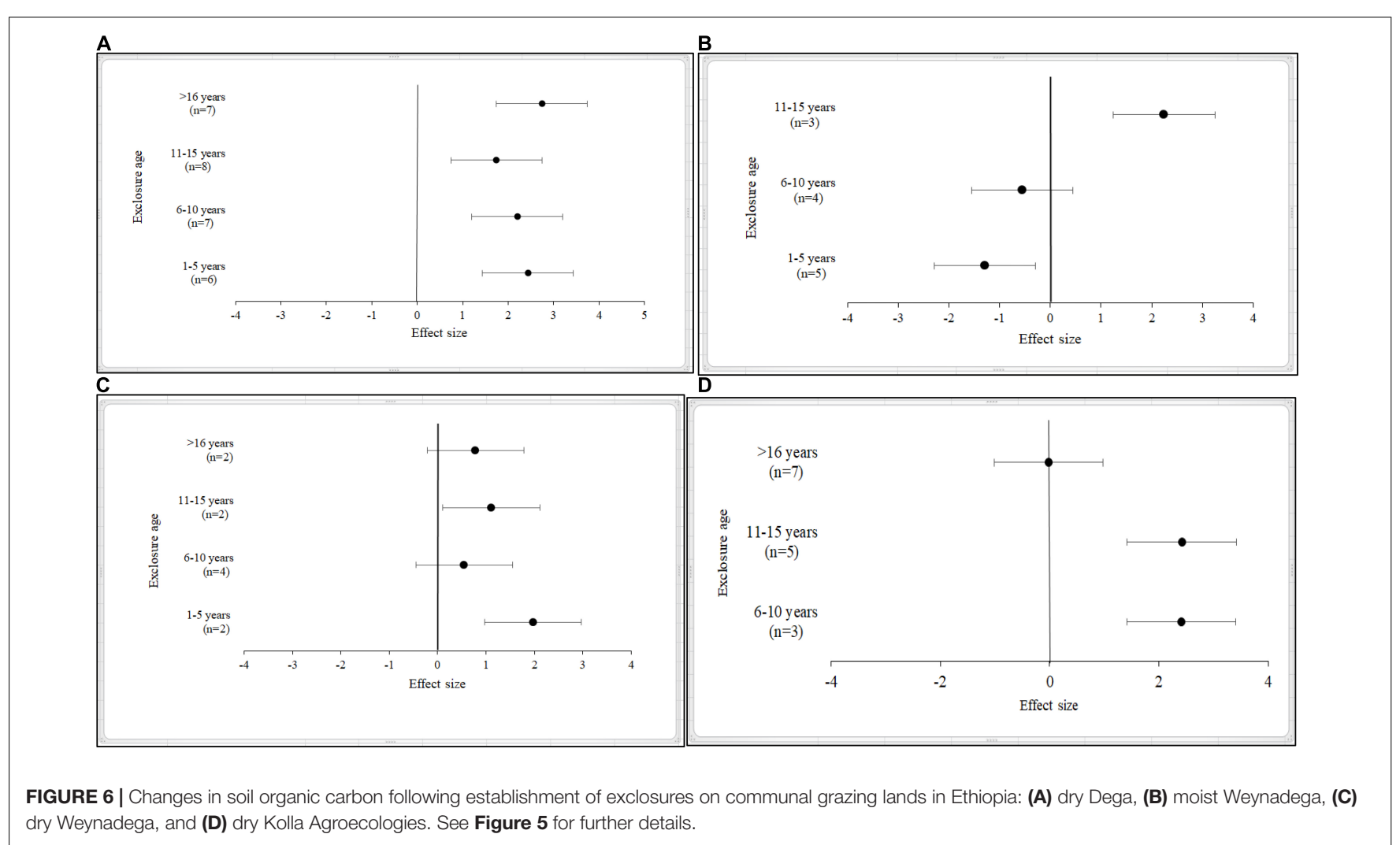


The studies did not cover all agroecological zones of Ethiopia (Figure 1; Hurni et al., 2015), and were distributed to nine agroecological zones (Figure 2) and most of the studies were concentrated in four agroecological zones, dry Weynadega (34\%), dry Dega (24\%), dry Kolla (11\%), and moist Weynadega (11\%). This could be attributed to the large coverage (covers $51.3 \%$ of the total land area of Ethiopia) of these agroecological zones and severity of land degradation. Table 2 presents the characteristics of the traditional agroecological zones of Ethiopia. The results also showed that most of the studies were conducted in areas dominated by Cambisols and Luvisols followed by Leptosols and Vertisols (Figure 3). This could be attributed to the large coverage of these soil types in Ethiopia (Jones et al., 2013). It is also noted that the soils of the study sites of the 30 papers considered for this meta-analyses were not evenly distributed across the five agroecological zones where most $(85 \%)$ of the studies were conducted (Figure 4).

\section{Changes in Soil Carbon Following the Establishment of Exclosures on Communal Grazing Lands}

Significant differences were observed in the magnitude of changes in soil organic $\mathrm{C}$ following the establishment of exclosures on communal grazing lands (Figures 5, 6 and Table 3). The results suggest that the magnitude of change in soil organic $\mathrm{C}$ varies with soil type, exclosure age, and agroecological zones (Figures 5, 6 and Table 3). The effect sizes were significantly positive for all soil types (Table 3 ). The magnitude of effect sizes varied with exclosure ages in all three soil types (Figures 5A-C). In two of the three soil types, the Cambisols and Luvisols, an increasing trend in soil organic $\mathrm{C}$ with exclosure age was observed, while no distinct trend was observed in Leptosols. In Cambisols and
Luvisols, the magnitude of effect sizes was significantly lower at younger age ( $<10$ years) compared to the older exclosures ( $>16$ years) (Figures 5 A-C).

In most cases, exclosures increased soil organic $\mathrm{C}$, although the magnitude of the effect sizes varied among agroecologies and exclosure age. For example, in Dry Dega region (see details in Table 2), the magnitude of the effect was larger compared to the other two agroecologies considered (Table 3). The effects of exclosure age on soil organic $\mathrm{C}$ in dry Weynadega and dry Kolla agroecologies were not significant (Figures 6C,D).

\section{Changes in Total Soil N Following the Establishment of Exclosures on Communal Grazing Lands}

Exclosures significantly improved total soil $\mathrm{N}$ in both Luvisols and Cambisols, but not in Leptosols where a net decrease was observed (Figure 7C and Table 4). There was an increase in total soil $\mathrm{N}$ in all agroecologies following the establishment of exclosures, but the effect size was smaller in Dry Kolla agroecology. In most cases, an increasing trend in total soil $\mathrm{N}$ with exclosure age was observed for the studied soil types (Figures 7A,B) and agroecologies (Figures 8A-D).

\section{Changes in Soil Bulk Density and pH Following the Establishment of Exclosures}

Exclosures significantly decreased soil bulk density irrespective of soil type and agroecology, except for Dry Dega (Table 5). Soil pH significantly increased in moist Weyna Dega following establishment of exclosures on communal grazing lands, while it significantly decreased in Dry Kolla; no significant effect was seen for other agroecologies or soil types (Table 6).

TABLE 3 | Changes in soil organic carbon after establishment of exclosures on communal grazing lands.

\begin{tabular}{|c|c|c|c|c|c|c|c|}
\hline & & Sample size & Overall effect size & Lower $95 \% \mathrm{Cl}$ & Upper $95 \%$ Cl & $p$-value & Dominant soil texture \\
\hline \multirow[t]{3}{*}{ Soil type } & Cambisols & 28 & $1.3 \pm 0.22$ & 0.85 & 1.69 & $<0.001$ & Clay \\
\hline & Luvisols & 15 & $1.0 \pm 0.45$ & 0.08 & 1.85 & 0.033 & Sandy clay loam \\
\hline & Leptosols & 15 & $1.3 \pm 0.34$ & 0.66 & 1.99 & $<0.001$ & Clay loam \\
\hline \multirow[t]{4}{*}{ Agroecologies } & Dry Dega & 32 & $2.0 \pm 0.25$ & 1.55 & 2.53 & $<0.001$ & Clay loam \\
\hline & Moist Weynadega & 12 & $-0.4 \pm 0.34$ & -1.12 & 0.22 & 0.189 & Sandy loam \\
\hline & Dry Weynadega & 12 & $1.0 \pm 0.30$ & 0.42 & 1.58 & $<0.001$ & Clay loam \\
\hline & Dry Kolla & 17 & $0.7 \pm 0.34$ & 0.05 & 1.38 & 0.036 & Clay loam \\
\hline
\end{tabular}

Cl refers to confidence interval in effect size; error terms given for overall effect size are standard errors.

TABLE 4 | Changes in total soil nitrogen after the establishment of exclosures on communal grazing lands.

\begin{tabular}{|c|c|c|c|c|c|c|c|}
\hline & & Sample size (n) & Overall effect size & Lower $95 \% \mathrm{Cl}$ & Upper $95 \%$ Cl & $p$-value & Soil texture \\
\hline \multirow[t]{3}{*}{ Soil type } & Cambisols & 31 & $0.3 \pm 0.13$ & 0.05 & 0.56 & 0.021 & Clay \\
\hline & Luvisols & 15 & $2.1 \pm 0.31$ & 1.47 & 2.67 & $<0.001$ & Clay loam \\
\hline & Leptosols & 11 & $-0.5 \pm 0.44$ & -1.40 & 0.34 & 0.230 & Clay loam \\
\hline \multirow[t]{4}{*}{ Agroecologies } & Dry Dega & 19 & $1.0 \pm 0.47$ & 0.12 & 1.95 & 0.027 & Clay loam \\
\hline & Moist Weynadega & 9 & $0.4 \pm 0.09$ & 0.17 & 0.55 & $<0.001$ & Cay loam \\
\hline & Dry Weynadega & 15 & $0.5 \pm 0.19$ & 0.16 & 0.91 & 0.005 & Clay \\
\hline & Dry Kolla & 17 & $0.1 \pm 0.15$ & -0.16 & 0.42 & 0.382 & Clay \\
\hline
\end{tabular}

See Table 3 for further details. 
A
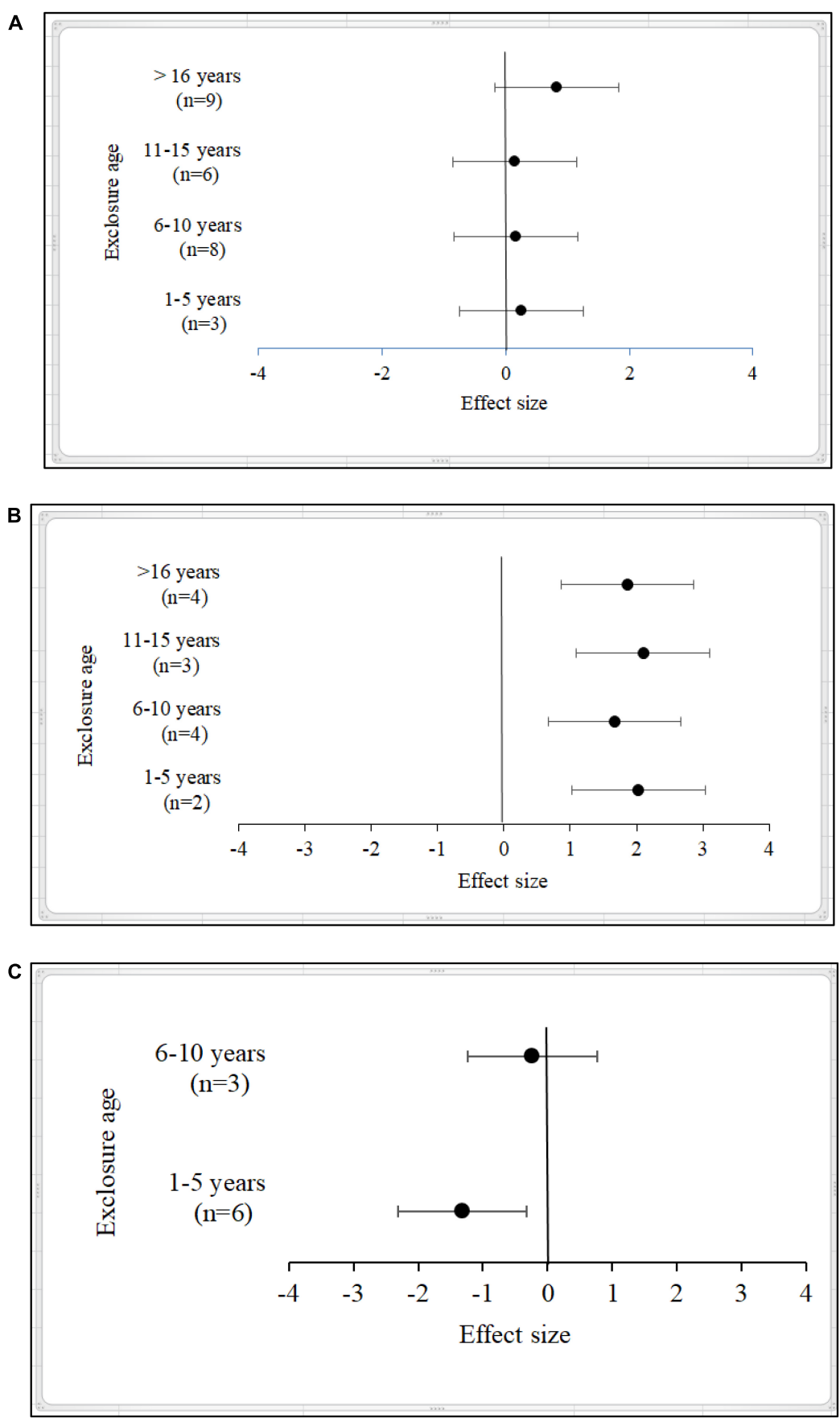

FIGURE 7 | Changes in total soil $\mathrm{N}$ after establishment of exclosures on communal grazing lands in Ethiopia: (A) Cambisols, (B) Luvisols, (C) Leptosols. See Figure 5 for further details.

\section{Effects of Landscape Positions on Soil Organic Carbon and Total Soil Nitrogen}

The effects of exclosures on restoring soil organic $\mathrm{C}$ and total soil $\mathrm{N}$ varied with landscape positions and the highest increase was observed at the foot slope position compare to the upper slope position (Figures 9A,B). Significant increase in total soil $\mathrm{N}$ and soil organic $\mathrm{C}$ were observed in all the three landscape positions.

\section{Differences in Soil Organic Carbon and Total Soil Nitrogen Among Exclosures, Cropland, and Eucalyptus Plantation}

Exclosures displayed significantly greater soil organic C compared to the adjacent cropland. The difference in soil organic $\mathrm{C}$ in exclosures and Eucalyptus plantations was not significant (Figure 10A). Significantly greater total soil $\mathrm{N}$ in the topsoil 
A

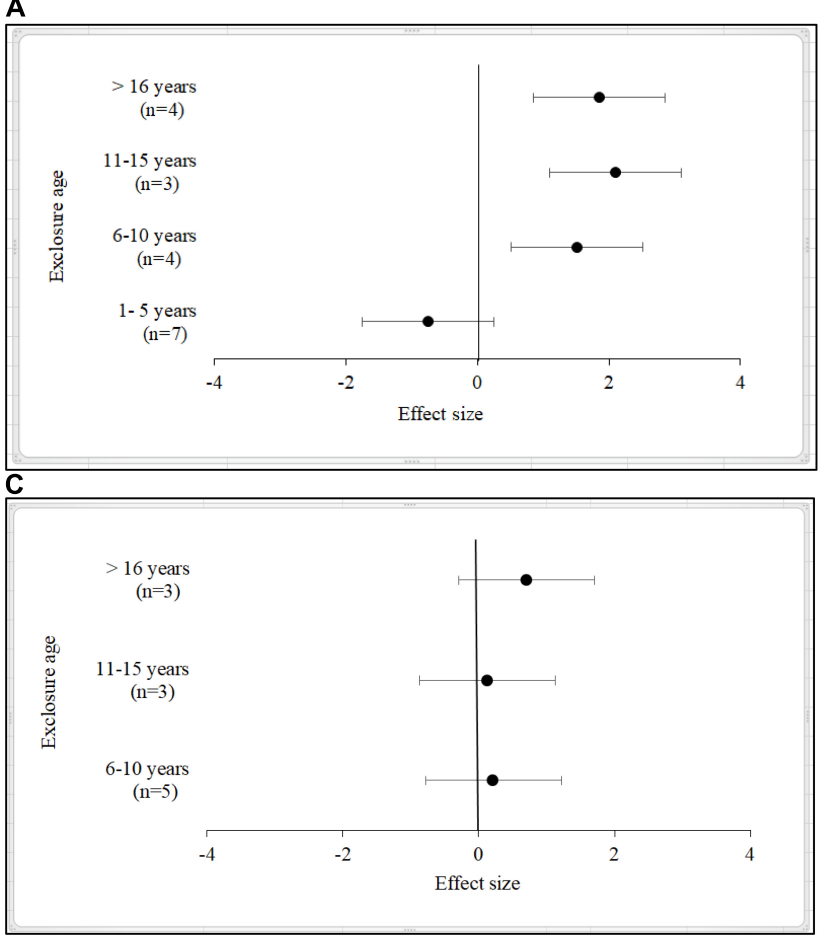

B

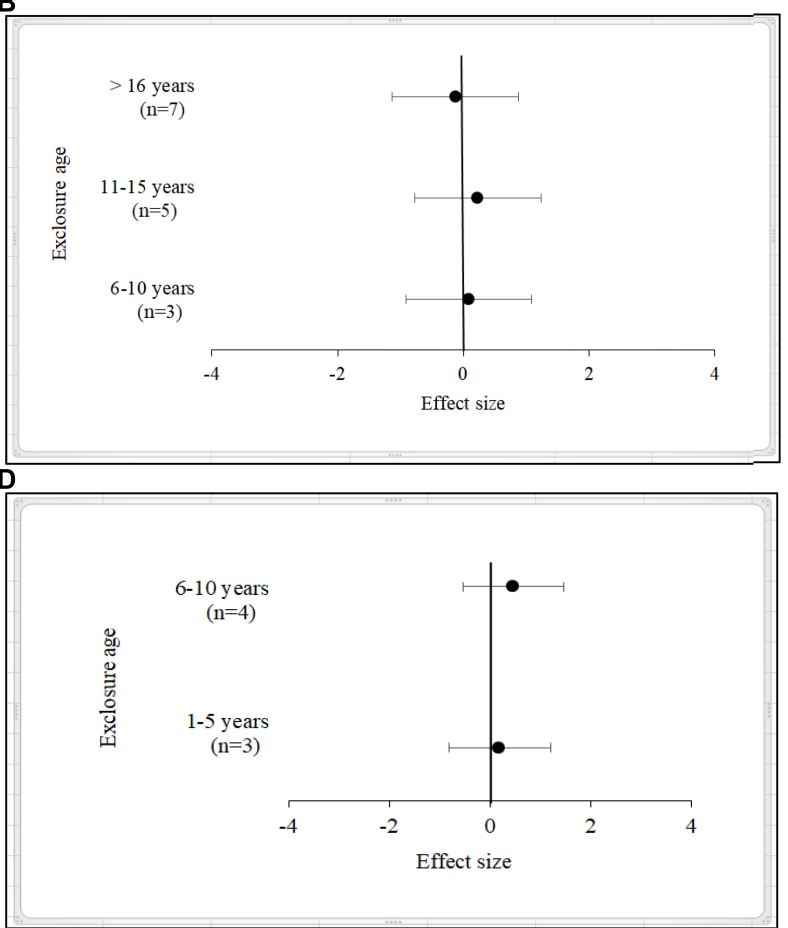

FIGURE 8 | Changes in total soil N after the establishment of exclosures on communal grazing lands in Ethiopia: (A) Dry Dega, (B) Dry Kolla, (C) Dry Weynadega, and (D) Moist Weynadega. See Figure 5 for further details.

TABLE 5 | Changes in soil bulk density following the establishment of exclosures on communal grazing lands.

\begin{tabular}{|c|c|c|c|c|c|c|}
\hline & & Sample size & Overall effect size & Lower $95 \% \mathrm{Cl}$ & Upper $95 \% \mathrm{Cl}$ & $p$-value \\
\hline & Luvisols & 20 & $-1.2 \pm 0.36$ & -1.94 & -0.53 & $<0.001$ \\
\hline & Moist Weynadega & 13 & $-1.9 \pm 0.41$ & -2.67 & -1.09 & $<0.001$ \\
\hline & Dry Weynadega & 14 & $-0.4 \pm 0.15$ & -0.69 & -0.10 & 0.009 \\
\hline & Dry Kolla & 13 & $-0.6 \pm 0.30$ & -1.23 & -0.04 & 0.036 \\
\hline
\end{tabular}

Leptosols not included as there were insufficient data available in the reviewed papers. See Table 3 for further details.

was recorded in exclosures than in cropland or Eucalyptus plantations (Figure 10B).

\section{DISCUSSION}

The increase in soil organic $\mathrm{C}$ and total soil $\mathrm{N}$ following the establishment of exclosures in Ethiopia with an effect size greater than two resulted in improvement in other key soil properties underpinning ecosystem services. The changes can be attributed to greater organic matter inputs to the soil through litter fall, decomposition of roots of herbaceous species and grasses, and protection of the site from soil erosion. The difference in the magnitude of the effect sizes among the three soil types was related to the texture of the dominant soil type (Table 3). The higher clay content of Cambisols and Luvisols could contribute to increased soil organic $\mathrm{C}$ accumulation as clay improves soil organic matter accumulation by protecting the organic matter from decomposition (López-Ulloa et al., 2005; Dlamini et al., 2016). A meta-analysis conducted in QinghaiTibetan Plateau (Liu et al., 2020) indicated that grazing exclusion in major grassland types (e.g., Alpine meadow) significantly increased soil organic carbon. Although this study reported the positive contribution of grazing exclusion, the results are not transferable to Ethiopia due to differences in types of grazing land, management and climate variables. Similarly, a metaanalysis by Yayneshet and Treydte (2015) across Sub-Saharan Africa detected higher soil organic $\mathrm{C}$ concentrations in exclosures than in communal grazing systems, but is not specific to the systems, soils and agroecological zones of Ethiopia.

The magnitude of the effect size varied with exclosure age. The lower effect size in soil organic $C$ at younger age ( $<10$ years) compared to the older exclosures ( $>16$ years) in both Cambisols and Luvisols could be attributed to the initial conditions of the 
TABLE 6 | Changes in soil pH following the establishment of exclosures on communal grazing lands.

\begin{tabular}{|c|c|c|c|c|c|c|}
\hline & & Sample size & Overall effect size & Lower $95 \% \mathrm{Cl}$ & Upper $95 \% \mathrm{Cl}$ & $p$-value \\
\hline Soil type & Luvisols & 23 & $0.2 \pm 0.21$ & -0.24 & 0.57 & 0.419 \\
\hline \multirow[t]{3}{*}{ Agroecologies } & Dry Dega & 12 & $0.8 \pm 0.39$ & -0.00 & 1.53 & 0.051 \\
\hline & Moist Weynadega & 12 & $0.6 \pm 0.20$ & 0.21 & 0.99 & 0.003 \\
\hline & Dry Weynadega & 10 & $0.1 \pm 0.48$ & -0.79 & 1.07 & 0.765 \\
\hline
\end{tabular}

See Table 3 for further details.
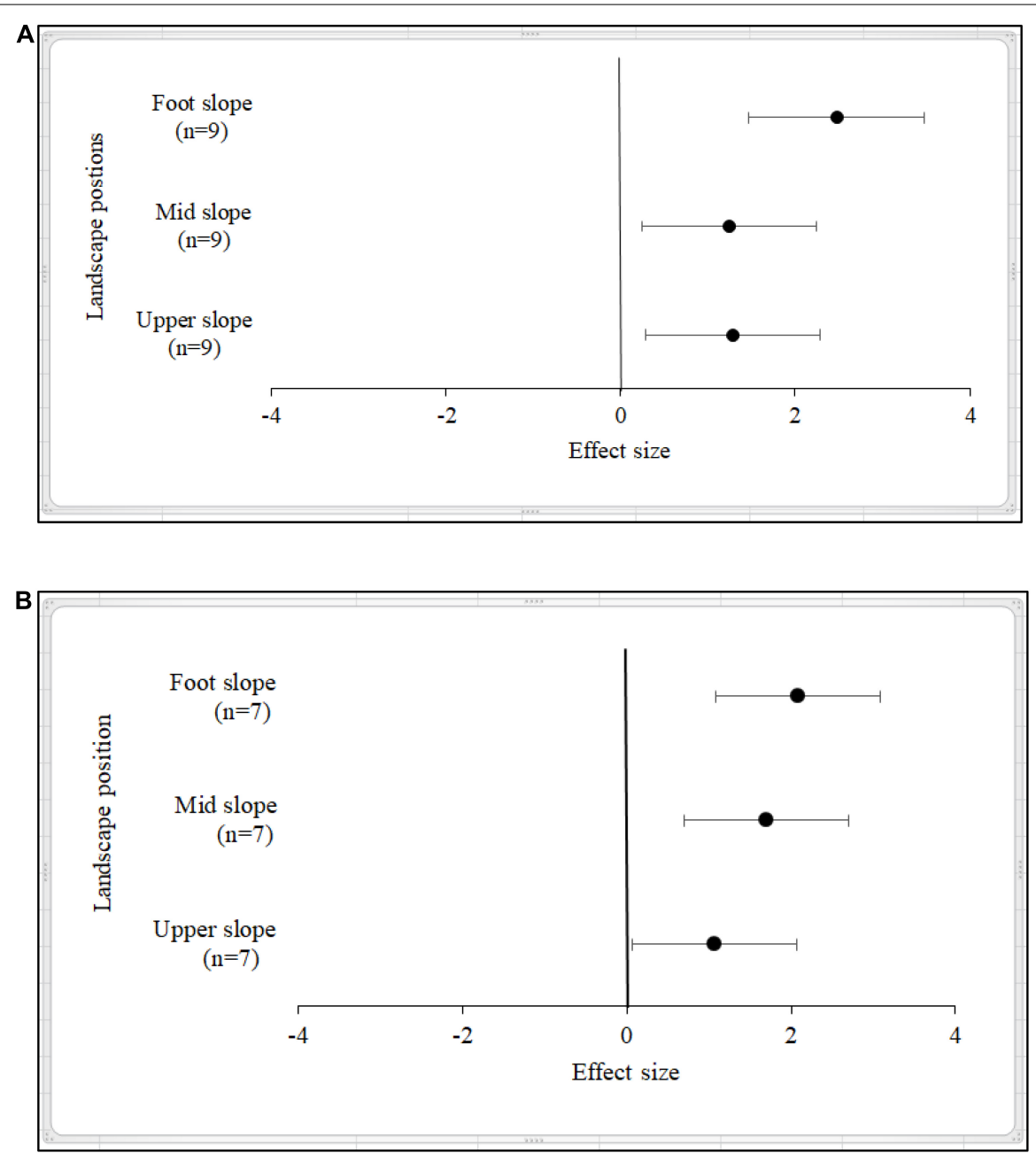

FIGURE 9 | Changes in soil organic carbon (A) and total soil nitrogen (B) following establishment of exclosures on communal grazing lands under three landscape positions; Foot slope, Mid-slope and Upper slope. See Figure $\mathbf{5}$ for further details.

sites before the establishment of the exclosures. Both Cambisols and Luvisols are typically used intensively for agriculture and grazing in Ethiopia (Rabia et al., 2013); this can result in severe degradation of soil organic $\mathrm{C}$ and total soil $\mathrm{N}$, requiring several years before the site is able to recover. A meta-analysis by Dlamini et al. (2016) carried out using 55 studies from across the globe indicated that degradation induced by livestock grazing considerably reduced soil organic C. Such global studies are key to providing a global perspective, but the changes observed are not specific to the situation in Ethiopia. This requires a focus on Ethiopian studies, as done in this study. In less well-developed Leptosols, a positive effect was observed from the early stages of exclosure establishment (Figure 5C), but the effect of exclosure age was less than observed in Cambisols and Luvisols. Leptosols 

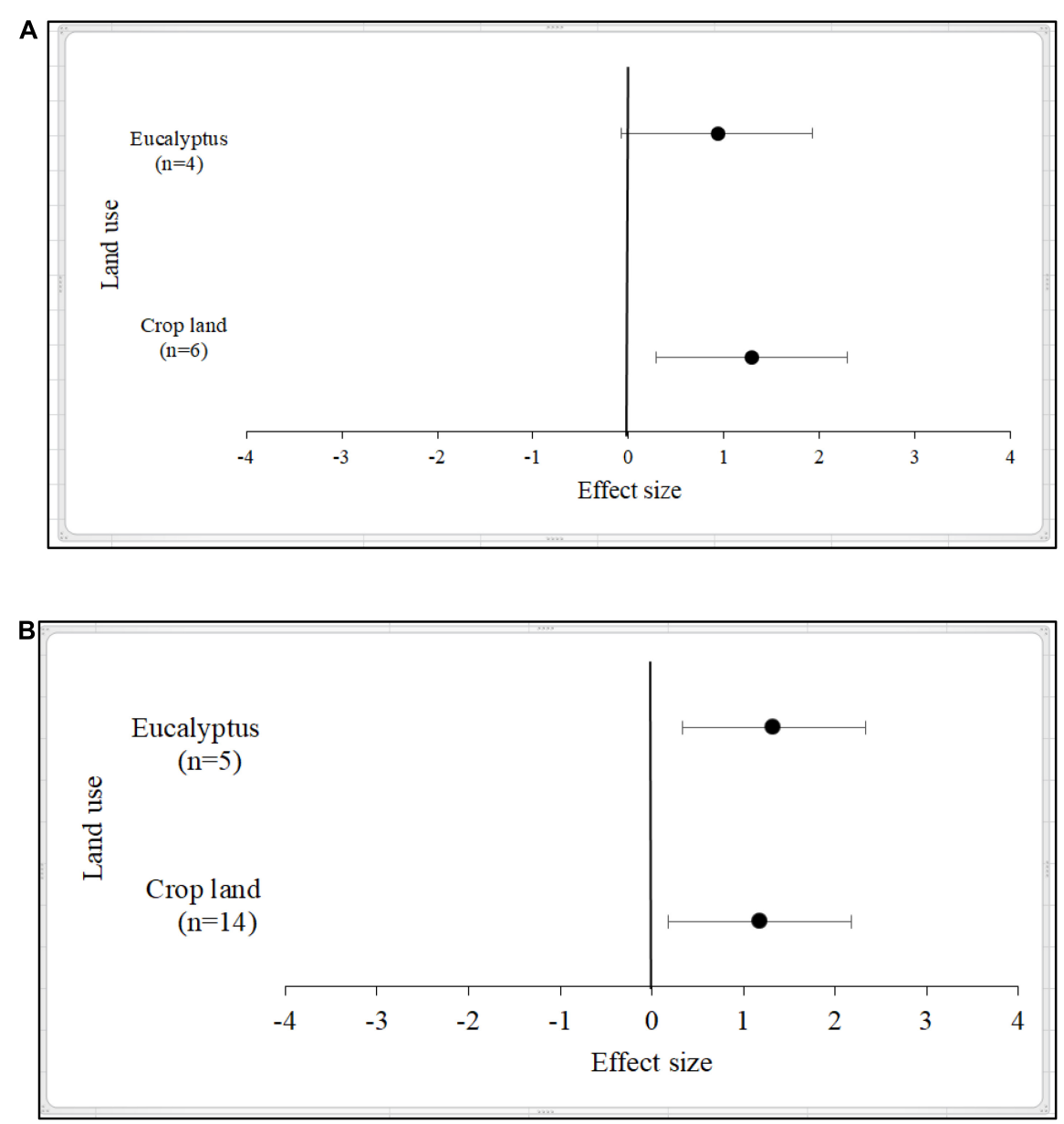

FIGURE 10 | Differences in soil organic carbon (A) and total soil nitrogen (B) among exclosures, cropland, and eucalyptus plantation. See Figure 5 for further details.

occur mainly on steep slopes and exclosures established on steep slopes usually have less encroachment by livestock and humans; this could increase the establishment of grasses in the exclosures at an early stage, with a positive early impact on soil organic C.

Differences in effect size in soil organic $\mathrm{C}$ among agroecologies could be attributed to the effect of climate (rainfall and temperature) on soil biogeochemical processes (mainly organic matter decomposition and $\mathrm{N}$ mineralization). Accumulation of organic matter in the soil can be greater under dry condition because of slowed organic C decomposition (Wang et al., 2016; Petraglia et al., 2019). The higher effect size in dry Dega could also be attributed to the dominance of both Cambisols and Luvisols in this agroecology (Figure 4). By contrast, in moist Weynadega agroecology, negative impacts of exclosures on soil organic $\mathrm{C}$ were observed (Table 3 ). The soils in exclosures displayed lower bulk densities (Table 5), which may result in increased soil moisture holding capacity. This, in turn, might increase the rate of soil organic matter decomposition and reduce soil organic C accumulation in the soils of the exclosures (Deng et al., 2014). The decrease in the effect size of exclosure age in soil organic $\mathrm{C}$ in dry Weynadega and dry Kolla agroecologies (Figures 6C,D) could be due to reduction in grass production and increase in woody plants or shrubs with time, which consequently reduced organic matter input due to litterfall and decomposition of fibrous roots.

The general trend of increases in total soil $\mathrm{N}$ after the establishment of exclosures on communal grazing lands could be explained by organic matter accumulation in exclosures derived from above ground biomass (trees, shrubs, and herbaceous species) (Yimer et al., 2015). The results of the study demonstrated that significant trends do not always follow soil organic $\mathrm{C}$ increases (Table 3 ). This could be attributed to the difference in the characteristics of litterfall accumulated in different sites (e.g., the C:N ratio). A meta-analysis by Liu et al. (2020) conducted using global data also demonstrated increases in total soil $\mathrm{N}$ stocks in topsoil $(0-30 \mathrm{~cm})$ following grazing exclusion. Another meta-analysis by Yayneshet and Treydte (2015) used data derived from Sub-Saharan African countries and reported significant increases in total soil $\mathrm{N}$ under complete exclusion of livestock.

A major driver for the reduction of bulk density following the establishment of exclosures on communal grazing lands was likely to be reduced soil compaction by livestock trampling, but increased soil organic $\mathrm{C}$ can also improve resilience to compaction (Zhang et al., 2005). Reduced soil bulk density in 
exclosures could increase soil aeration, water absorption, and water holding capacity and reduce runoff (Kozlowski, 1999; Lal and Kimble, 2001) which in turn could affect soil organic C accumulation by improving physical conditions for plant growth.

The effects of landscape positions on soil organic $\mathrm{C}$ and total soil $\mathrm{N}$ reported in this study could be attributed to increased soil moisture in lower slopes and biomass production (Danalatos et al., 1995) and hence organic matter addition to the soil. Furthermore, removal of materials (e.g., top soils) from upper slopes and deposition in lower slopes could contribute to improved soil organic $\mathrm{C}$ and total soil $\mathrm{N}$ in the foot slopes (Mekuria et al., 2018; Welemariam et al., 2018).

The significant difference between exclosures and adjacent cropland in soil organic $\mathrm{C}$ and total soil $\mathrm{N}$ can be explained by the deterioration of soil structure in cropland due to agricultural disturbance (Gelaw et al., 2014), continuous tillage operations (Kibet et al., 2016) and removal of crop residues (Gelaw et al., 2014; Abegaz et al., 2016; Araya et al., 2016; Negasa et al., 2017), which are major causes of soil organic $\mathrm{C}$ and total soil $\mathrm{N}$ losses from cultivated lands.

Planning in Ethiopia for establishment of exclosures requires a better understanding of the factors controlling their effectiveness for restoring soil organic $\mathrm{C}$ and total soil N. Our analysis of available research suggests that the impacts of exclosures differ according to soil type, exclosure age, landscape position, agroecology, and severity of land degradation. The results demonstrate that the focus of the Ethiopian government on establishing exclosures on severely degraded communal grazing lands should broaden to less degraded landscapes. The results also suggest that the establishment of exclosures should initially be concentrated in drier agroecologies because significantly more soil organic $\mathrm{C}$ and total soil $\mathrm{N}$ can be restored in dry than in humid areas. Establishing exclosures on steep slopes of Leptosols will achieve improvements in soil organic $\mathrm{C}$ and total soil $\mathrm{N}$ immediately after exclosure establishment ( $<10$ years). Such

\section{REFERENCES}

Abegaz, A., Winowiecki, L. A., Vagen, T. G., Langan, S., and Smith, J. U. (2016). Spatial and temporal dynamics of soil carbon in landscapes of the upper Blue Nile Basin of the Ethiopian Highlands. Agric. Ecosyst. Environ. 218, 190-208. doi: 10.1016/j.agee.2015.11.019

Adimassu, Z., Kessler, A., Yirga, C., and Stroosnijder, L. (2013). Farmers' perceptions of land degradation and their investments in land management: a case study in the central Rift Valley of Ethiopia. Environ. Manag. 51, 989-998. doi: 10.1007/s00267-013-0030-z

Aerts, R., Nyssen, J., and Haile, M. (2009). On the difference between "exclosures" and "enclosures" in ecology and the environment. J. Arid Environ. 73, 762-763. doi: 10.1016/j.jaridenv.2009.01.006

Araya, T., Nyssen, J., Ovaerts, B., Deckerse, J., Sommer, R., Bauer, H., et al. (2016). Seven years resource-conserving agriculture effect on soil quality and crop productivity in the Ethiopian dry lands. Soil Tillage Res. 163, 99-109. doi: 10.1016/j.still.2016.05.011

Cohen, J. (1969). Statistical Power Analysis for the Behavioral Sciences. New York, NY: Academic Press.

Danalatos, N. G., Kosmas, C. S., Moustakas, N. C., and Yassoglou, N. (1995). Rock fragments: II. Their impact on soil physical properties and biomass production positive short-term impacts are also likely on Cambisols and Luvisols, which have deeper topsoil, if exclosures are established on less degraded soils. In the long term ( $>15$ years), considerable improvements are likely in exclosures established on Cambisols and Luvisols, irrespective of the severity of soil degradation. This meta-analysis has provided initial criteria that can be used when planning exclosures to restore soil organic $\mathrm{C}$ and total soil $\mathrm{N}$ (focus on less degraded soils, drier agroecologies, and Leptosols, Cambisols, and Luvisols), but there is a need for further field measurements in exclosures across Ethiopia to better capture the diverse impacts of exclosures in different agroecologies, soil types and cropping practices. In particular, data are concentrated in northern Ethiopia, so surveys should be extended to other regions.

\section{AUTHOR CONTRIBUTIONS}

All authors listed have made a substantial, direct, and intellectual contribution to the work, and approved it for publication.

\section{FUNDING}

This work is part of the RALENTIR (Reducing land degradation and carbon loss from Ethiopia's soils to strengthen livelihoods and resilience) project, funded by UK Research and Innovation GCRF (Global Challenges Research Fund, project reference ES/T003073/1) and the University of Aberdeen.

\section{ACKNOWLEDGMENTS}

We are grateful to Abeyou Wale for his assistance in developing the map of agroecological zones of Ethiopia.

under Mediterranean conditons. Soil Use Manag. 11, 121-126. doi: 10.1111/j. 1475-2743.1995.tb00509.x

Deng, L., Liu, G., and Shangguan, Z. (2014). Land-use conversion and changing soil carbon stocks in China's "grain-for-green" program: a synthesis. Glob. Chang. Biol. 20, 3544-3556. doi: 10.1111/gcb.12508

Descheemaeker, K., Nyssen, J., Rossi, J., Poesen, J., Haile, M., Raes, D., et al. (2006). Sediment deposition and pedogenesis in exclosures in the Tigray highlands, Ethiopia. Geoderma 132, 291-314. doi: 10.1016/j.geoderma.2005.0 4.027

Dlamini, P., Chivenge, P., and Chaplot, V. (2016). Overgrazing decreases soil organic carbon stocks the most under dry climates and low soil $\mathrm{pH}$ : a metaanalysis shows. Agric. Ecosyst. Environ. 221, 258-269. doi: 10.1016/j.agee.2016. 01.026

Ebabu, K., Tsunekawa, A., Haregeweyn, N., Adgo, E., Tsegaye, D., Aklog, D., et al. (2019). Effects of land use and sustainable land management practices on runoff and soil loss in the Upper Blue Nile basin, Ethiopia. Sci. Total Environ. 648, 1462-1475. doi: 10.1016/j.scitotenv.2018.08.273

Gebre, A. B., Birhane, E., Gebresamuel, G., Hadgu, K. M., and Norgrove, L. (2019). Woody species diversity and carbon stock under different land use types at Gergera watershed in eastern Tigray, Ethiopia. Agrofor. Syst. 93, 1191-1203. doi: 10.1007/s10457-018-0226- 
Gelaw, A. M., Singh, B. R., and Lal, R. (2014). Soil organic carbon and total nitrogen stocks under different land-uses in a semi-arid watershed in Tigray, Northern Ethiopia. Agric. Ecosyst. Environ. 188, 256-263. doi: 10.1016/j.agee.2014.0 2.035

Gessesse, T. A., Khamzinab, A., Gebresamuela, G., and Amelung, W. (2020). Terrestrial carbon stocks following 15 years of integrated watershed management intervention in semi-arid Ethiopia. Catena 190:104543. doi: 10. 1016/j.catena.2020.104543

Girmay, G., Singh, B. R., Nyssen, J., and Borrosen, T. (2009). Runoff and sedimentassociated nutrient losses under different land uses in Tigray, Northern Ethiopia. J. Hydrol. 376, 70-80. doi: 10.1016/j.jhydrol.2009.07.066

Global Mechanism of the UNCCD, Conservation International, and DIE (2019). Land Degradation, Poverty and Inequality. Bonn: UNCCD.

Gurevitch, J., and Hedges, L. V. (1999). Statistical issues in ecological metaanalyses. Ecology 80, 1142-1149. doi: 10.1890/0012-9658(1999)080[1142: siiema]2.0.co;2

Haregeweyn, N., Tsunekawa, A., Nyassen, J., Poesen, J., Tsubo, M., Meshesha, D. T., et al. (2015). Soil erosion and conservation in Ethiopia: a review. Prog. Phys. Geogr. 39, 750-774. doi: 10.1177/0309133315598725

Hedges, L. V. (1981). Distribution theory for Glass's estimator of effect size and related estimators. J. Educ. Stat. 6, 107-128.

Holden, S. T., Shiferaw, B., and Pender, J. (2001). Market imperfections and land productivity in the Ethiopian Highlands. J. Agric. Econ. 52, 62-79.

Hurni, K., Zeleke, G., Kassie, M., Tegegne, B., Kassawmar, T., Teferi, E., et al. (2015). Economics of Land Degradation (ELD) Ethiopia Case Study. Soil Degradation and Sustainable Land Management in the Rainfed Agricultural Areas of Ethiopia: An Assessment of the Economic Implications. Report for the Economics of Land Degradation Initiative. Addis Ababa: Water and Land Resource Centre (WLRC), 94.

IPBES (2018). "The IPBES assessment report on land degradation and restoration," in Secretariat of the Intergovernmental Science-Policy Platform on Biodiversity and Ecosystem Services, eds L. Montanarella, R. Scholes, and A. Brainich (Bonn: IPBES), 744

Jones, A., Breuning-Madsen, H., Brossard, M., Dampha, A., Deckers, J., and Dewitte, O (eds.) (2013). Soil Atlas of Africa. European Commission. Luxembourg: Publications Office of the European Union, 176.

Kibet, L. C., Blanco-Canqui, H., and Jasa, P. (2016). Long-term tillage impacts on soil organic matter components and related properties on a Typic Argiudoll. Soil Tillage Res. 155, 78-84. doi: 10.1016/j.still.2015.05.006

Kozlowski, T. T. (1999). Soil compaction and growth of woody plants. Scand. J. For. Res. 14, 596-619. doi: 10.1080/02827589908540825

Lal, R. (2010). Enhancing eco-efficiency in agro-ecosystems through soil carbon sequestration. Crop Sci. 50, S-120-S-131.

Lal, R., and Kimble, J. M. (2001). "Importance of soil bulk density and methods of its measurement," in Assessment Methods for Soil Carbon, eds R. Lal, J. M. Kimble, R. F. Follett, and B. A. Stewart (New York, NY: Lewis Publishers), 31-44.

Liu, X., Sheng, H., Wang, Z., Ma, Z., Huang, X., and Li, L. (2020). Does grazing exclusion improve soil carbon and nitrogen stocks in alpine grasslands on the qinghai-tibetan plateau? A meta-analysis. Sustainability 12:977. doi: 10.3390/ su12030977

López-Ulloa, M., Veldkamp, E., and de Koning, G. H. J. (2005). Soil carbon stabilization in converted tropical pastures and forests depends on soil type. Soil Sci. Soc. Am. J. 69, 1110-1117. doi: 10.2136/sssaj2004.0353

Mekuria, W., Veldkamp, E., Corre, M. D., and Haile, M. (2011). Restoration of ecosystem carbon stocks following exclosure establishment in communal grazing lands in tigray, Ethiopia. Soil Sci. Soc. Am. J. 75, 246-256. doi: 10.2136/ sssaj2010.0176

Mekuria, W., Veldkamp, E., Haile, M., Gebrehiwot, K., Muys, B., and Nyssen, J. (2009). Effectivenss of exclosures to control soil erosion and local communities' perception on soil erosion. Afr. J. Agric. Res. 4, 365-377.

Mekuria, W., Wondie, M., Amare, T., Wubet, A., Feyisa, T., and Yitaferu, B. (2018). Restoration of degraded landscapes for ecosystem services in North-Western Ethiopia. Heliyon 4, e00764. doi: 10.1016/j.heliyon.2018. e00764
Mekuria, W., Gebregziabher, G., and Lefore, N. (2020). Exclosures for Landscape Restoration in Ethiopia: Business Model Scenarios and Suitability (IWMI Research Report 175). Colombo: International Water Management Institute (IWMI), 62. doi: 10.5337/2020.201

Negasa, T., Ketema, H., Legesse, A., Sisay, M., and Temesgen, H. (2017). Variation in soil properties under different land use types managed by smallholder farmers along the toposequence in southern Ethiopia. Geoderma 290, 40-50. doi: 10.1016/j.geoderma.2016.11.021

Neglo, K. A. W., Gebrekidan, T., and Lyu, K. Y. (2021). The role of agriculture and non-farm economy in addressing food insecurity in Ethiopia: a review. Sustainability 13:3874. doi: 10.3390/su13073874

Nyssen, J., Poesen, J., Moeyersons, J., Deckers, J., and Haile, M. (2006). Processes and rates of rock fragment displacement on cliffs and scree slopes in an amba landscape, Ethiopia. Geomorphology 81, 265-275. doi: 10.1016/j.geomorph. 2006.04.021

Nyssen, J., Poesen, J., Moeyersons, J., Deckers, J., Haile, M., and Lang, A. (2004). Human impact on the environment in the Ethiopian and Eritrean highlandsa state of the art. Earth Sci. Rev. 64, 273-320. doi: 10.1016/s0012-8252(03) 00078-3

Petraglia, A., Cacciatori, C., Chelli, S., Fenu, G., Calderisi, G., and Gargano, D. (2019). Litter decomposition: effects of temperature driven by soil moisture and vegetation type. Plant 435, 187-200. doi: 10.1007/s11104-0183889-x

Rabia, A. A., Afifi, R. R., Gelaw, A. M., Bianchi, S., Figueredo, H., Huong, T. L., et al. (2013). Soil mapping and classification: a case study in the Tigray Region, Ethiopia. J. Agric. Environ. Int. Dev. 107, 73-99.

Rosenberg, M. S., Adams, D. C., and Gurevitch, J (eds.) (2000). MetaWin: Statistical Software for Meta-Analysis. Sunderland, MA: Sinauer Associates.

Rossiter, J., Minale, M. W., Andarge, W., and Twomlow, S. (2017). A communities Eden - grazing Exclosure success in Ethiopia. Int. J. Agric. Sustain. 15, 514-526. doi: 10.1080/14735903.2017.1352059

SDG Report (2019). The Sustainable Development Goals Report 2021. New York, NY: United Nation, 2019.

Teketay, D., Lemenih, M., Bekele, T., Yemshaw, Y., Feleke, S., Tadesse, W., et al. (2010). "Forest resources and challenges of sustainable forest management and conservation in Ethiopia," in Degraded Forests in Eastern Africa: Management and Restoration, eds F. Bongers and T. Tennigkeit (London: Earthscan), 19-63.

Wallace, B. C., Lajeunesse, M. J., Dietz, G., Dahabreh, I. J., Trikalinos, T. A., Schmid, C. H., et al. (2017). OpenMEE: intuitive, open-source software for meta-analysis in ecology and evolutionary biology. Methods Ecol. Evol. 2017, 941-947. doi: 10.1111/2041-210X.12708

Wang, D., He, N., Wang, Q., Lü, Y., Wang, Q., Xu, Z., et al. (2016). Effects of temperature and moisture on soil organic matter decomposition along elevation gradients on the Changbai Mountains, Northeast China. Pedosphere 26, 399-407. doi: 10.1016/S1002-0160(15)6 0052-2

Welemariam, M., Kebede, F., Bedadi, B., and Birhane, E. (2018). Exclosures backed up with community-based soil and water conservation practices increased soil organic carbon stock and microbial biomass carbon distribution, in the northern highlands of Ethiopia. Chem. Biol. Technol. Agric. 5:12. doi: 10.1186/ s40538-018-0124-1

Woldeamlak, B. (2006). Soil and water conservation intervention with conventional technologies in northwestern highlands of Ethiopia: acceptance and adoption by farmers'. Land Use Policy 24, 404-416. doi: 10.1016/j.landusepol.2006.05.004

World Bank (2016). Ethiopia: Priorities of Ending Extreme Poverty and Promoting Shared Prosperity Systematic Country Diagnostics. Washington, DC: World Bank, 18.

Yayneshet, T., and Treydte, A. C. (2015). A meta-analysis of the effects of communal livestock grazing on vegetation and soils in sub-Saharan Africa. J. Arid Environ. 116, 18-24.

Yimer, F., Alemu, G., and Abdelkadir, A. (2015). Soil property variations in relation to exclosure and open grazing land use types in the Central Rift Valley area of Ethiopia. Environ. Syst. Res. 4:17. doi: 10.1186/s40068-0150041-2 
Zhang, B., Horn, R., and Hallett, P. (2005). Mechanical resilience of degraded soil amended with organic matter. Soil Sci. Soc. Am. J. 69, 864-871. doi: 10.2136/ sssaj2003.0256

Conflict of Interest: The authors declare that the research was conducted in the absence of any commercial or financial relationships that could be construed as a potential conflict of interest.

Publisher's Note: All claims expressed in this article are solely those of the authors and do not necessarily represent those of their affiliated organizations, or those of the publisher, the editors and the reviewers. Any product that may be evaluated in this article, or claim that may be made by its manufacturer, is not guaranteed or endorsed by the publisher.

Copyright (C) 2022 Yakob, Smith, Nayak, Hallett, Phimister and Mekuria. This is an open-access article distributed under the terms of the Creative Commons Attribution License (CC BY). The use, distribution or reproduction in other forums is permitted, provided the original author(s) and the copyright owner(s) are credited and that the original publication in this journal is cited, in accordance with accepted academic practice. No use, distribution or reproduction is permitted which does not comply with these terms. 